\title{
Variability of the bushcricket Ephippiger ephippiger: RAPDs and song races
}

\author{
MICHAEL G. RITCHIE*, SETH N. RACEY, JENNIFER M. GLEASON \& KIRSTEN WOLFF \\ Biological and Medical Sciences, Bute Medical Building, University of St Andrews, St Andrews, Fife, \\ Scotland KY16 9TS, U.K.
}

\begin{abstract}
The tettigoniid bushcricket, Ephippiger, shows extensive variability in morphology and behaviour in Western Europe. Several species and subspecies have been described, but many may only represent local forms of uncertain origin. Within Ephippiger ephippiger, patterns of variation differ between morphology (upon which most taxonomic forms are defined) and behaviour. There is sufficient variation in a sexual signal (calling song) within the species that 'song races' have been described, which show strong premating isolation from each other. Here RAPD markers (138 fragments from 10 primers) have been used to examine the extent and pattern of genetic differentiation within the species and between two congeneric species. Ephippiger ephippiger is clearly distinguished from its relatives. High genetic similarity has been found within E. ephippiger, Nei and Li's $S$ averaging 0.67 . Using both distance and parsimony methods resolves the relationships of the song races and morphological forms of E. ephippiger with the exception of one population. The song races represent the deepest division within the species, but the lack of concordance in different traits suggests that a complex pattern of subspecific variation is found within this species.
\end{abstract}

Keywords: bushcricket, Ephippiger, phylogeny, RAPD markers, song, speciation.

\section{Introduction}

Many groups of organisms contain high levels of cryptic diversity, either because of unrecognized sibling species or because single species can contain a variety of undetected subspecies. Spectacular examples of cryptic sibling species are insect taxa, such as Enchenopa (Wood, 1993) and Chrysoperla (Henry, 1985). Enchenopa is a complex of hemipteran species differing in host plant use, and Chrysoperla is a complex of neuropteran species differing in sexual signalling behaviour. Both were thought to be single or a few species until detailed studies of their ecology, behaviour and taxonomy were carried out. Also, there are now known to be many cases in which single species have been found to consist of a patchwork of subspecies or races, some showing extensive differentiation, connected by areas of hybridization (Harrison \& Rand, 1985; Hewitt, 1988, 1989). It has been suggested that a major cause of differentiation may be behavioural change, particularly of sexual signalling systems (Butlin \& Ritchie, 1994; Henry, 1994). This follows the observation

*Correspondence. E-mail: mgr@st-andrews.ac.uk that mating signals, such as courtship songs or pheromones, can differ dramatically between cryptic species (e.g. Löfstedt, 1993; Wells \& Henry, 1994; Ritchie \& Gleason, 1995), although an intriguing suggestion is that sexual selection can drive post- as well as premating isolation (Wu et al., 1996).

Given such diversity, it is not surprising that the taxonomy of some of the evolutionarily most interesting species is often poorly understood or contentious. Crickets of the genus Ephippiger provide an example of such taxonomic confusion. Harz (1969), the standard taxonomic reference for European tettigoniids, recognized 12 species within the genus, with E. ephippiger further subdivided into five subspecies. More recent studies have proposed uniting several of these species. Hartley \& Warne (1984), on the basis of genitalic morphology and mating compatibilities, reduced $E$. ephippiger to three subspecies, E. e. ephippiger east of the Alps, $E$. e. vitium in Western Europe and E. e. cunii in the Pyrenees. Duijm and colleagues (Duijm \& Oudman, 1983; Duijm et al., 1983), on the basis of a similar study, concluded that none of these forms is reproductively isolated and united them all in a 'superspecies', E. e. diurnus Kruseman (henceforth called 
simply E. ephippiger to avoid confusion). Subsequent detailed study of both morphology and allozymes seemed to confirm this with no diagnostic traits for each subspecies and clinal variation linking each proposed distinguishing trait (Duijm, 1990; Oudman et al., 1989, 1990). Hence E. ephippiger could be a case in which the original taxonomy overestimated the number of evolutionary species present in a species complex.

The origins of the forms of E. ephippiger are not clear. Subspecific variation of other species from this part of Europe can often be related to differentiation in refugia during recent ice ages, with subsequent dispersal producing multiple, concordant clines in many traits across major geographical barriers, such as the Alps or Pyrenees (Hewitt, 1996). Busnel (1963) and Grandcolas (1987) suggested that the variation in E. ephippiger may reflect secondary hybridization. However, Oudman et al. (1990) rejected this because of nonconcordance of the clines for different traits. Rather, they envisaged very recent in situ variation resulting from drift and selection, with the clines being of primary rather than secondary origin. Nei's genetic distances, calculated from four allozyme loci, were very low, around 0.03 between most forms (one eastern form, E. e. vicheti, was more distinct).

Male calling song might influence speciation in tettigoniids because of its role in reproductive isolation. Song has been studied in some detail in Ephippiger because of unusual patterns of variability. It is produced by elytral stridulation and each wing movement produces a 'syllable' of song. Ephippiger ephippiger song is polymorphic. Throughout most of its range, it is monosyllabic, with clinal variation to polysyllabic forms (i.e. having multiple syllables per chirp) around the western coast of the Mediterranean and in the eastern Pyrenees (Duijm, 1990). These have been termed 'song races' (Ritchie, 1991) and are quite independent of the morphological criteria upon which Harz (1969) distinguished taxonomic forms. Other close relatives of $E$. ephippiger also vary in song structure. Ephippiger provincialis is polysyllabic and $E$. terrestris monosyllabic. Ritchie (1991, 1992, 1996) has shown that females have strong preferences for the song of their own race. The differences in song and preference are genetic and sufficiently strong that the song races would probably show strong premating isolation were they to become sympatric.

Here, the genetic differentiation within this group is examined using RAPD markers (Welsh \& McClelland, 1990, Williams et al., 1990). RAPD markers have the advantage of ease of development, but the disadvantage of considerable confusion over their independence and homology, leading some to question their use in molecular phylogeography (Stammers et al., 1995; van de Zande \& Bijlsma, 1995). Despite this, several studies have used them successfully in phylogenetic analysis (Demeke et al., 1992; Stiles et al., 1993; Badaracco et al., 1995; Stammers et al., 1995; Comincini et al., 1996; Millan et al., 1996). A consensus opinion seems to be that RAPDs are reliable for intraspecific variation, but become unreliable as phylogenetic distance increases (Grosberg et al., 1996; Rieseberg, 1996). The success of tests for homology may in part relate to the genetic distance separating the taxa involved (e.g. Stammers et al., 1995 vs. van de Zande \& Bijlsma, 1995). In a study of sunflower species of greater genetic distance than the forms studied here, Rieseberg (1996) found that over 90 per cent of 220 co-migrating fragments were homologous (although 13 per cent were paralogous). The extent of variation in RAPD markers between the supposed subspecies and song races of E. ephippiger was measured and compared with the good taxonomic species, E. terrestris and E. provincialis, plus a heterogeneric outgroup. It is concluded that RAPDs provide useful markers for studying variation in this group and we discuss the evolution of the variation seen within this species.

\section{Materials and methods}

Specimens of the races of E. ephippiger and the species E. terrestris, E. provincialis and Steropleurus (syn. Uromenus) catalaunicus were collected from southern France and refrigerated in 96 per cent ethanol (Table 1 and Fig. 1; morphological type refers to the specific or subspecific name used by Harz, 1969). Ephippiger provincialis is rare, probably endangered, and only a single specimen was available. Steropleurus catalaunicus was included as an outgroup and is from the same subfamily as Ephippiger.

DNA was extracted from dissected leg or thoracic muscle using the Puregene DNA isolation kit (Gentra Systems) following the protocol for animal tissue. Amplification reactions were performed in 25 $\mu \mathrm{L}$ using single $10 \mathrm{mer}$ primers (Operon, CA, U.S.A.; Table 2). Each reaction contained $12.5 \mathrm{ng}$ of DNA, $0.2 \mathrm{~mm}$ each dNTP, $2.5 \mathrm{~mm} \mathrm{MgCl}_{2}, 5 \mathrm{pmol}$ of primer and 0.5 units of Dynazyme DNA polymerase (Flowgen) in Dynazyme buffer (Flowgen). The polymerase chain reaction (PCR) programme using a PCT 100 thermal cycler (MJ Research) consisted of denaturation at $94^{\circ} \mathrm{C}$ for $3 \mathrm{~min}$, followed by 45 cycles 
Table 1 Origin and description of samples of bushcrickets used

\begin{tabular}{lllll}
\hline Species (site) & Population, département & $\begin{array}{l}\text { Morphological } \\
\text { type }\end{array}$ & Song type & $\begin{array}{c}\text { No. of } \\
\text { individuals }\end{array}$ \\
\hline E. ephippiger (1) & Valensole, Alpes de Haute Provence & Vitium & Monosyllabic & 4 \\
E. ephippiger (2) & Montpellier, Hérault & Cruciger & Monosyllabic & 5 \\
E. ephippiger (3) & Llar, Pyrénées Orientales & Cunii & Polysyllabic & 5 \\
E. ephippiger (4) & Sauto, Pyrénées Orientales & Cunii & Polysyllabic & 5 \\
E. ephippiger (5) & LePuch, Ariège & Cunii & Polysyllabic & 1 \\
E. ephippiger (6) & Querigut, Ariège & Cunii & Polysyllabic & 2 \\
E. terrestris (7) & Seyne, Alpes de Haute Provence & & Monosyllabic & 3 \\
E. terrestris (8) & Col du Labouret, Alpes de Haute Provence & & Monosyllabic & 5 \\
E. provincialis (9) & Plan d'Aups, Var & Polysyllabic & 1 \\
Steropleurus catalaunicus $(10)$ & Estavar, Pyrénées Orientales & Polysyllabic & 4 \\
\hline
\end{tabular}

Site codes for use with Fig. 1.

of denaturation at $94^{\circ} \mathrm{C}$ for $30 \mathrm{~s}$, annealing at $40^{\circ} \mathrm{C}$ for $30 \mathrm{~s}$, an increase of $0.4^{\circ} \mathrm{C} \mathrm{s}^{-1}$ to $72^{\circ} \mathrm{C}$ and extension at $72^{\circ} \mathrm{C}$ for $90 \mathrm{~s}$. After the last cycle, there was a $72^{\circ} \mathrm{C}$ extension for $4 \mathrm{~min}$. PCR products were resolved on a 1.4 per cent agarose gel run at a constant $90 \mathrm{~V}$ for $4-5 \mathrm{~h}$, stained with ethidium bromide and photographed under UV light.

An initial survey of 31 primers was performed and 10 were selected to be used for the final analysis. These were chosen on the clarity and number of bands produced rather than the incidence of band sharing. The 10 final RAPD profiles were scored independently by two of us, one of whom had no knowledge of which individuals were in each lane, to produce a presence/absence data matrix for each band. Independent analyses of each data matrix gave extremely similar results, and only one set (that from the 'blind' scoring) is presented here.

\section{Data analysis}

There seems to be remarkably little consensus concerning methods of analysing patterns in RAPD data. Distance methods are most commonly used, although principal coordinate analysis (a multivariate analysis of overall similarity) is also common. The nature of the data set seems suitable for parsimony (Hadrys et al., 1992), but this is not often used. Stiles et al. (1993) found different distance measures gave a similar result, consistent with tradi-
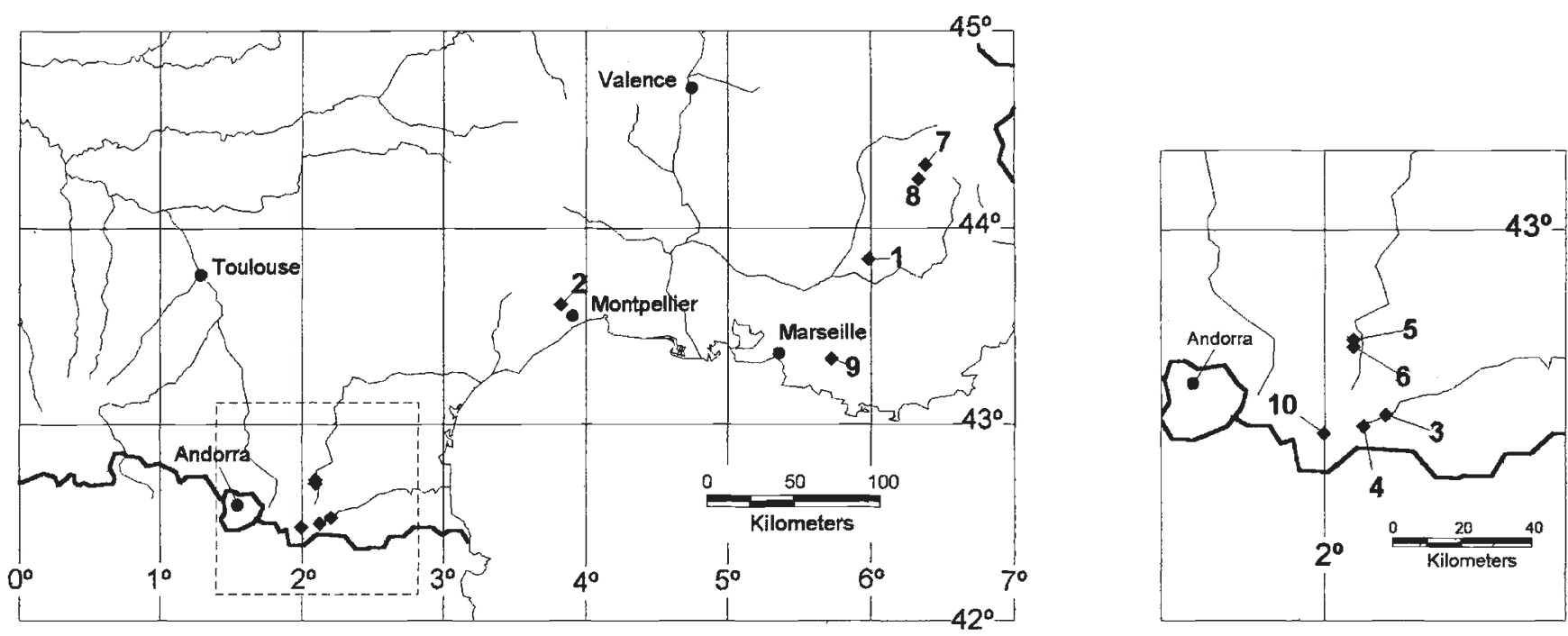

Fig. 1 Maps of southern France and the eastern Pyrenees showing the approximate positions of collection sites (see Table 1 for codes). 
Table 2 Primers used and extent of polymorphism seen in bushcrickets

\begin{tabular}{|c|c|c|c|c|}
\hline Primer $\left(5^{\prime}-3^{\prime}\right)$ & $\begin{array}{c}\text { Number of } \\
\text { bands }\end{array}$ & $\begin{array}{l}\text { Number } \\
\text { variable }\end{array}$ & $\begin{array}{l}\text { Number of } \\
\text { bands in } \\
\text { E. ephippiger }\end{array}$ & $\begin{array}{l}\text { Number of } \\
\text { polymorphic } \\
\text { bands in } \\
\text { E. ephippiger }\end{array}$ \\
\hline OPA1 CAGGCCCTTC & 11 & 10 & 9 & 8 \\
\hline OPA2 TGCCGAGCTG & 15 & 15 & 11 & 11 \\
\hline OPA3 AGTCAGCCAC & 15 & 15 & 10 & 6 \\
\hline OPA7 GAAACGGGTG & 14 & 14 & 12 & 12 \\
\hline OPA10 GTGATCGCAG & 16 & 16 & 14 & 14 \\
\hline OPA11 CAATCGCCGT & 16 & 16 & 12 & 12 \\
\hline OPH1 GCTCGGAGAA & 13 & 13 & 13 & 13 \\
\hline OPH5 AGTCGTCCCC & 12 & 12 & 11 & 8 \\
\hline OPH12 ACGCGCATGT & 13 & 12 & 12 & 11 \\
\hline OPH20 GGGAGACATC & 13 & 12 & 11 & 7 \\
\hline Totals & 138 & 135 & 115 & 102 \\
\hline
\end{tabular}

tional taxonomic interpretations, whereas parsimony gave a less easily interpreted result. Here, distance and parsimony techniques are compared.

A distance matrix was generated from the presence/absence data matrix using the RAPDPLOT program of Black (1995). This produces two distance matrices. The first is from a similarity (band sharing) index $S=2 N_{a, b} /\left(N_{a}+N_{b}\right)$, where $N_{a}$ and $N_{b}$ are the number of bands in individuals $a$ and $b$ and $N_{a, b}$ is the number of shared bands, after Nei \& Li (1979). The second also takes into account as informative the number of shared band absences (total matches/ total number of sites). The latter potentially confounds nonhomologous mutations that result in the lack of a PCR product (Grosberg et al., 1996), so only results for $S$ are presented (in practice, similar results were obtained with the overall similarity, but with one difference described later). Phenograms were produced from the distance matrices using the neighbour-joining algorithm in PHYLIP 3.57c (Felsenstein, 1993). To examine the robustness of the resulting pattern, the original matrix was bootstrapped 50 times (each had to be manually analysed via the RAPDPLOT program) and a consensus tree was prepared. Rieseberg (1996) suggested that such tests of robustness are particularly important for RAPDbased distance analyses. Individuals with any missing values in the original data matrix caused by nonamplification or band ambiguity were omitted, so the bootstrapped data sets have fewer individuals.

The same presence/absence data matrix was used in parsimony analyses using the DOLLOP program in PHYLIP 3.57c (Felsenstein, 1993) using Dollo parsi- mony and jumbling 500 times. A consensus of the resulting 31 trees was obtained using CONSENSE. For the bootstrap analysis, 100 replicates with 10 jumbles each were used.

\section{Results}

Table 2 shows the extent of polymorphism found. In total, 138 bands were scored, 98 per cent of which were variable. Within E. ephippiger, 115 bands were found, of which 89 per cent were variable. The extent of band sharing was high, $S$ averaging 0.62 within the entire data set and 0.67 within E. ephippiger. Figure 2 shows the phenogram produced by neighbour-joining analysis. Ephippiger ephippiger is clearly distinguished from the outgroup, E. terrestris and $E$. provincialis. With the exception of the Querigut population of E. ephippiger, the species separates into two groups reflecting the song races, with a Pyreneen polysyllabic race (conforming to the 'cunii' form of Harz) and a lowland monosyllabic form (consisting of both the 'cruciger' and 'vitium' forms, which are themselves distinguished). The bootstrapped phenogram (Fig. 3) confirms the robustness of the differences between species and the groupings of individuals within populations. However, it does not resolve the relative positions of the three major forms of E. ephippiger with the two relevant nodes being consistent in 50 per cent or less of the replicates. Trees produced simply from the overall match in RAPD pattern (results not shown), i.e. including shared band absences, differed in only one respect. The Montpellier population, representing the 'cruci- 


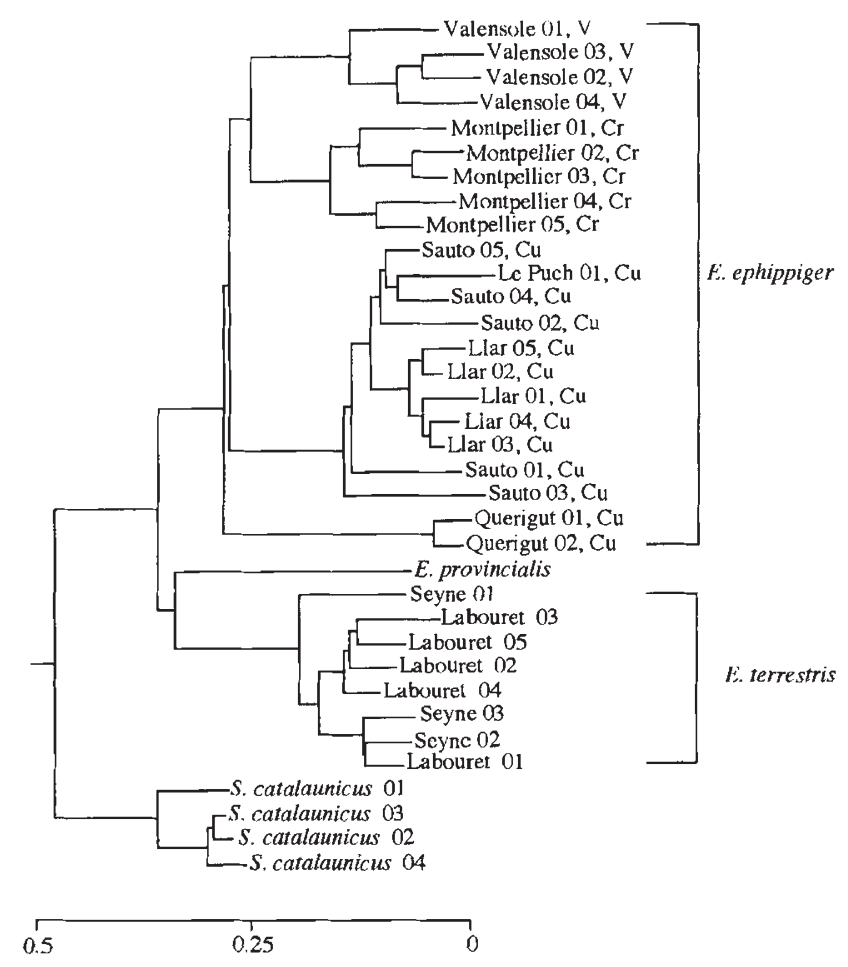

Fig. 2 Neighbour-joining tree from the RAPD profiles of all individual bushcrickets used in the study. The codes following $E$. ephippiger individuals' names indicate the morphological type ( $\mathrm{V}$, vitium; $\mathrm{Cu}$, cunii; $\mathrm{Cr}$, cruciger). ger' form of Harz, was included in the Pyreneen group (the 'cunii' form), producing a pattern substantially at odds with both geographical context and the song forms.

Thirty-one most parsimonious trees were obtained with a length of 495 steps. A consensus tree (Fig. 4) indicates that in all trees the Querigut population is the sister taxon of the Valensole population. This clade is the sister taxon to the Montpellier population, whereas the other E. ephippiger populations form a separate clade. However, the bootstrap analysis (Fig. 5) shows that the results are not robust. The relationships between the major clades of E. ephippiger are unresolved, although the Pyreneen forms, with the exception of Querigut, form one clade. In general, the bootstrap values for each group are much lower than in the distance analysis. As in the neighbour-joining analysis, the monosyllabic species E. terrestris is the sister taxon of the polysyllabic E. provincialis.

\section{Discussion}

The taxa studied show a very high level of band sharing (any pair of individuals examined was likely to share about 70 per cent of all bands, and the minimum level of band sharing seen was 35 per cent throughout all the specimens, 44 per cent within $E$. ephippiger). The high level of band sharing within $E$. ephippiger strongly supports the contention that the

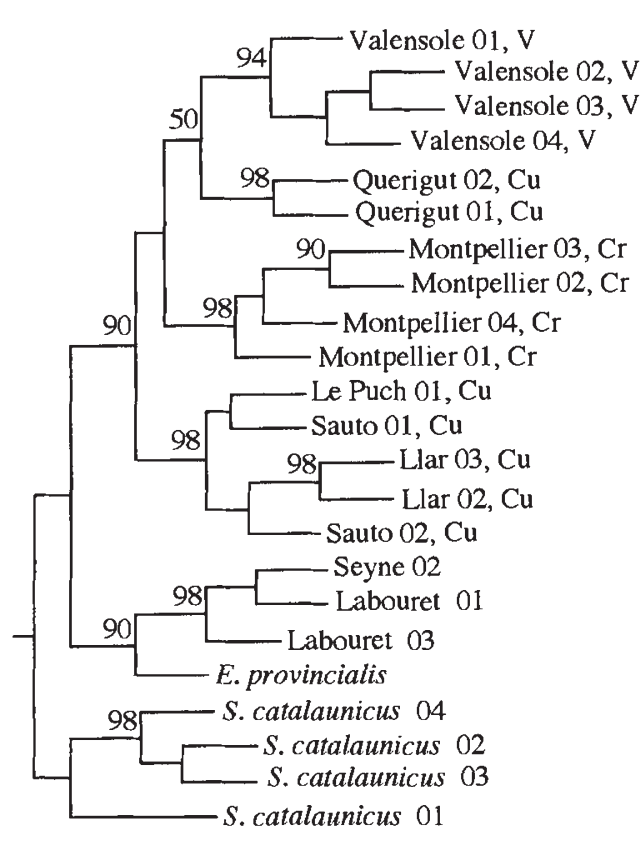

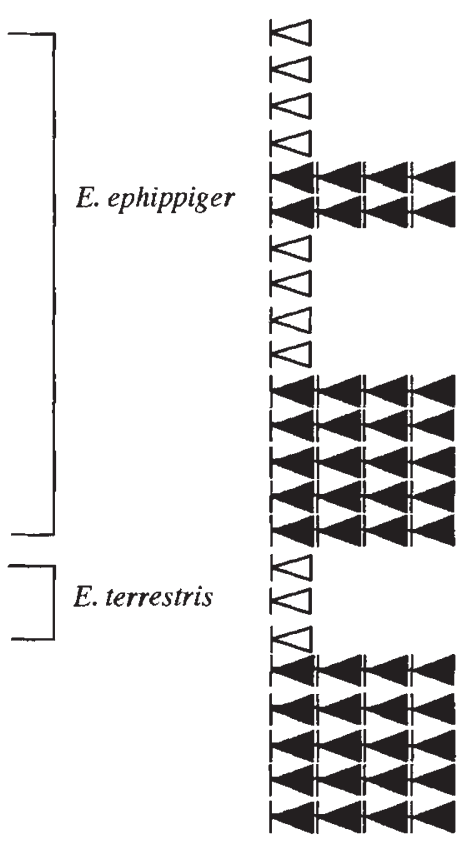

Fig. 3 Bootstrapped neighbourjoining tree after 50 replications. Numbers at the nodes indicate the percentage of trees with that node (omitted if in less than 50 per cent of trees). Codes are as in Fig. 1 and the icons to the right indicate song type (solid, polysyllabic; empty, monosyllabic). 
Fig. 4 Consensus tree of 31 minimum length trees of 495 steps found by Dollo parsimony. Numbers at each node indicate the percentage of the 31 trees in which the node occurred.

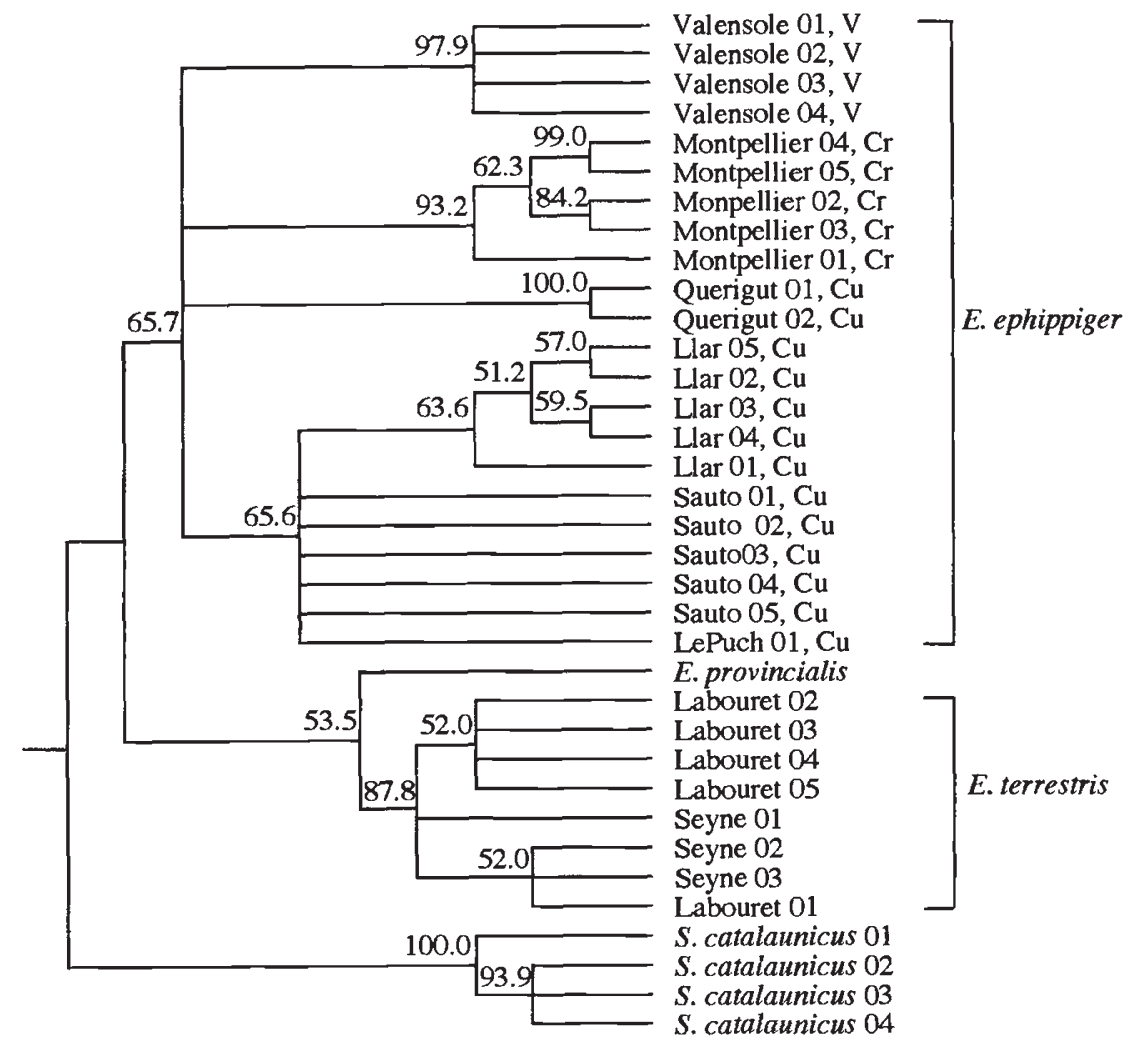

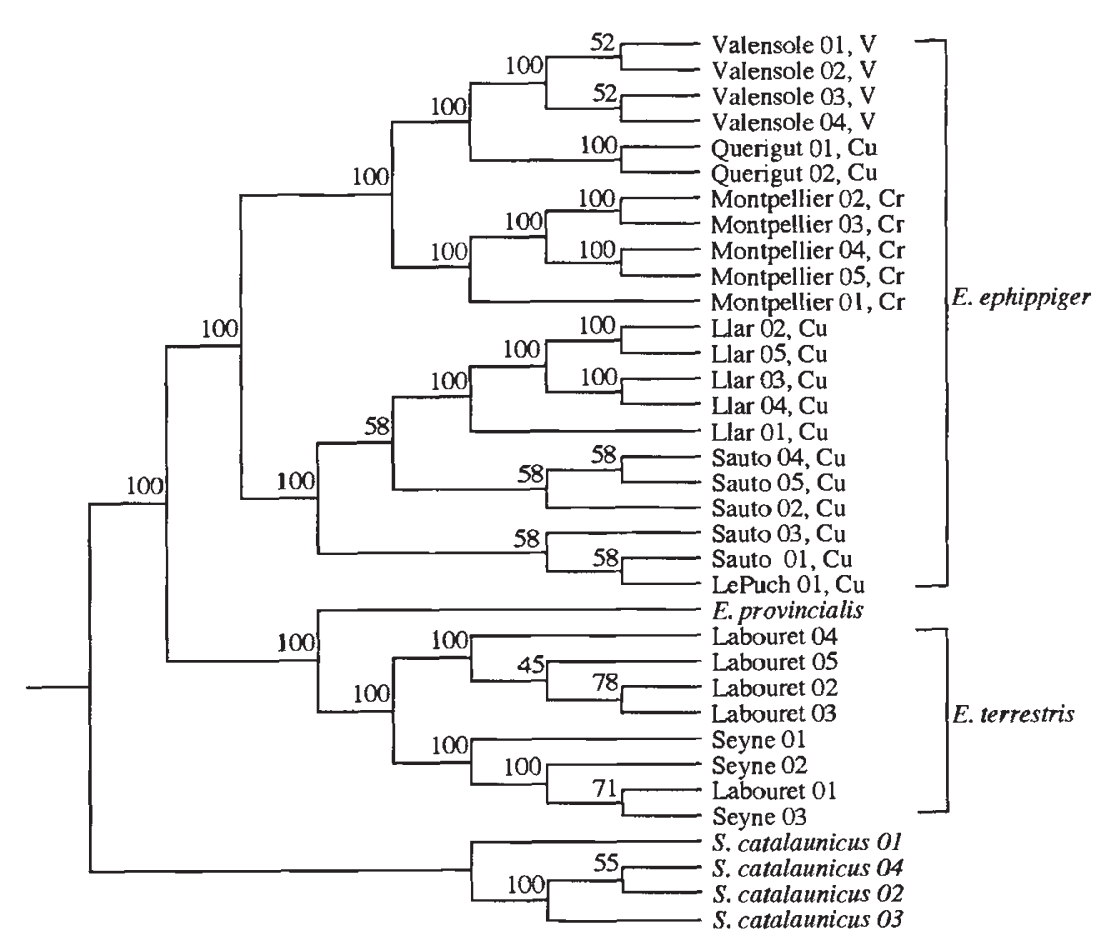

Fig. 5 Bootstrapped Dollo parsimony tree after 100 replications. The number at the node indicates the percentage of trees in which the node occurs. Nodes occurring in less than 50 per cent of the trees have been collapsed. (c) The Genetical Society of Great Britain, Heredity, 79, 286-294. 
races are very recently diverged. RAPDs therefore seem suitable for the phylogeographical analysis of Ephippiger.

The distance method of phylogenetic construction resolved the species well, confirming the distinctness of forms thought to be good species (E. provincialis and $E$. terrestris). In general, relationships were confirmed by the parsimony method, although the support was not as strong. Using distance methods, band sharing gave a more easily interpretable phenogram than the overall pattern of matches (including shared band absences). This may be because it is possible to have multiple nonhomologous mutations resulting in shared band absences, thus confounding phylogenetic analysis. Perhaps the most intriguing result of the phylogenetic analysis is the contrast between the strong consistency of the minimum length trees found by parsimony (Fig. 4) and the weaker support found when bootstrapping these data (Fig. 5). This must occur because a few species- or race-specific bands are consistently found by parsimony and contribute strongly to the pattern within the original data, but are sometimes omitted from the resampled data. We therefore strongly agree with Rieseberg (1996) that bootstrapping should be routinely applied to RAPD-based phylogenetic analyses. Given that his studies also suggest that 10 per cent of bands can be nonhomologous, and band independence remains a problem with the technique, inheritance studies or sequence characterization of bands of high weighting to phylogenetic patterns must be strongly encouraged for particularly important or long-term studies.

The biggest division within Western races of $E$. ephippiger is into two forms, Pyreneen and lowland French (Figs 2 and 4). This split could be seen as supporting the recognition of the 'cunii' (Pyreneen) form of Harz (1969), but the high genetic similarity, existence of numerous broad clines and lack of clear concordance in morphology or behaviour still argue against a simple pattern of variation in this species. The lack of concordance between trait variation described by Oudman et al. (1990) is reflected here by Querigut's position in the phenograms, which is in disagreement with its behaviour and geographical location. This could perhaps be explained if this population has exchanged substantial gene flow with the lowland form. However, the Le Puch population is actually the most northern of the Pyreneen samples and is geographically quite close to Querigut (Fig. 1), yet remains firmly within the Pyreneen clade. Both populations are polysyllabic, but of lower syllable number than the main Pyreneen 'cunii' form. Further sampling is needed to resolve the patterning of geographical variation further, but these results do suggest that the Pyreneen genotype is relatively local, not extending far outside of the Pyrenees-Orientales area, despite the much more wide-ranging clinal variation in song (Duijm, 1990). The conclusion of Oudman et al. (1990) that $E$. ephippiger is a single species in Western Europe, which is undergoing extensive local differentiation, rather than a heterogeneous mosaic of forms brought together following secondary contact, may be justified. However, changes of genotype during dispersal from ice age refugia and mixing resulting from multiple range expansions could substantially alter simple secondary patterns of subspecific variation (Hewitt, 1996).

The results described here confirm that the song races of $E$. ephippiger represent subspecific variation. A recent origin of these races makes the extent of behavioural isolation seen between them remarkable. When given a choice between song types, females rarely orientate to song from the wrong race, and this preference is robust because it is independent of differences in intensity (Ritchie, 1991; compare Doherty \& Howard, 1996). It is possible for sexual signalling systems to evolve rapidly, and several species show premating isolation or divergent mating signals in the absence of clear genetic differentiation in other traits (Butlin \& Ritchie, 1994; Henry, 1994; Ritchie \& Gleason, 1995). With an estimate of phylogenetic relationships, it is possible to deduce more accurately the course of evolution of sexual signalling systems, for example in determining the relative likelihood of sensory exploitation, co-evolving sexual selection (Meyer et al., 1994; Ryan \& Rand, 1995; Cocroft \& Ryan, 1995) or convergence. Our phenogram suggests that polysyllabic song is ancestral and that monosyllabic song has evolved twice, once in the evolution of E. terrestris and again to produce the monosyllabic forms of E. ephippiger. Supporting this is the observation that $E$. terrestris females have a distribution of preferences, which is more tightly matched to the male song (i.e. an E. terrestris female has a more strict requirement for only one syllable of song than females of the monosyllabic race of $E$. ephippiger). More outgroups need to be examined to confirm this interpretation, however. In general, the distribution of female preferences closely matches that of the male trait, implying that both have coevolved (Ritchie, 1996).

If speciation in groups such as crickets occurs because of divergence in mating behaviours (Henry, 1994; Ritchie \& Gleason, 1995; Wu et al., 1995; compare Harrison \& Bogdanowicz, 1995), the song 
races are more likely to represent evolutionarily significant divergence than the morphological criteria more commonly used for taxonomy. The largest genetic division within E. ephippiger is almost congruent with the variation in song pattern. This pattern could be confirmed by further studies, for example within $E$. ephippiger and across the genus, examining the predictive value of behaviour vs. other traits in explaining the distribution of genetic variation.

\section{Acknowledgements}

This work was funded by the NERC (advanced fellowship GT5/92/TLS/16 and grant GR9/02393 to M.G.R.). We are very grateful to David Kidd for preparing Fig. 1, and also to Stephen Phillips, Colin Hartley, Matthijs Duijm, Bill Black and Joe Felsenstein.

\section{References}

BADARACCO, G., BELlorinı, M. AND LANDSBERGER, N. 1995. Phylogenetic study of bisexual Artemia using random amplified polymorphic DNA. J. Mol. Evol., 41, 150-154.

BLACK, w. C., 1V. 1995. FORTRAN Programs for the Analysis of RAPD-PCR Markers in Populations. Colorado State University, Department of Microbiology, Fort Collins, CO.

BuSNel, M.-C. 1963. Charactérisation acoustique de populations d'Ephippiger écologiquement voisines. Ann. Epiphyties, 14, 25-34.

BUTLIN, R. K. AND RiTCHIE, M. G. 1994. Mating behaviour and speciation. In: Slater, P. J. B. and Halliday, T. R. (eds) Behaviour and Evolution, pp. 43-79. Cambridge University Press, Cambridge.

COCROFT, R. B. AND RYAN, M. J. 1995. Patterns of advertisement call evolution in toads and chorus frogs. Anim. Behav. 49, 283-303.

COMINCIN1, S., SIRON1, M., BANDI, C., GIUNTA, C., RUBIN1, M. AND FONTANA, F. 1996. RAPD analysis of systematic relationships among the Cervidae. Heredity, 76, 215-221.

DEMEKE, T., ADAMS, R. P. AND CH1BBAR, M. 1992. Potential taxonomic use of random amplified polymorphic DNA (RAPD): a case study in Brassica. Theor. Appl. Genet., 84, 990-994.

DOHERTY, J. A. AND HOWARD, D. J. 1996. Lack of preference for conspecific calls in female crickets. Anim. Behav., 51, 981-990.

DulJM, M. 1990. On some song characteristics in Ephippiger (Orthoptera: Tettigonioidae) and their geographic variation. Neth. J. Zool., 40, 428-453.

DUIJM, M. AND OUDMAN, L. 1983. Interspecific mating in Ephippiger (Orthoptera: Tettigonioidae). Tijd. $v$. Entomol., 126, 97-108.
DuiJM, M., OUdman, L. AND veldstra, B. G. 1983. Copulation in Ephippiger (Orthoptera, Tettigonioidae). Tijd. $v$. Entomol., 126, 91-96.

FELSENSTEIN, 3. 1993. PHYLIP (Phylogeny Inference Package) version 3.5p. Distributed by the author. Department of Genetics, University of Washington, Seattle.

GRANDCOLAS, P. 1987. Distribution and hybridization of species of the genus Ephippiger Bert. 1827 in the Briançon and Vallouise regions (Hautes-Alpes, France). In: Baccetti, B. (ed.) Evolutionary Biology of Orthopteroid Insects, pp. 240-245. Ellis Horwood, Chichester.

GRosberg, R. K., LEVITAN, D. R. AND CAMERON, B. B. 1996. Characterization of genetic structure and genealogies using RAPD-PCR markers: a random primer for the novice and nervous. In: Ferraris, J. D. and Palumbi, S. R. (eds) Molecular Zoology Advances, Strategies and Protocols, pp. 67-100. Wiley-Liss, New York.

HADRYS, H., BALICK, M. AND SCH1ERWATER, B. 1992. Applications of random amplified polymorphic DNA (RAPD) in molecular ecology. Mol. Ecol., 1, 55-63.

HARRISON, R. G. AND BOGDANOWICZ, s. M. 1995. Mitochondrial DNA phylogeny of North American field crickets: perspectives on the evolution of life cycles, songs, and habitat associations. J. Evol. Biol., 8, 209-232.

HARRISON, R. G. AND RAND, D. M. 1989. Mosaic hybrid zones and the nature of species boundaries. In: Otte, D. and Endler, J. A. (eds) Speciation and its Consequences, pp. 111-133. Sinauer Associates, Sunderland, MA.

HARTLEY, J. C. AND WARNE, A. C. 1984. Taxonomy of the Ephippiger ephippiger complex (ephippiger, cruciger and cunii) with special reference to the mechanics of copulation. Eos, 60, 43-54.

HARZ, K. 1969. Die Orthopteren Europas I. Dr W. Junk, The Hague.

HENRY, C. S. 1985. Sibling species, call differences, and speciation in green lacewings (Neuroptera, Chrysopidae, Chrysoperla). Evolution, 39, 965-984.

HENRY, C. S. 1994. Singing and cryptic speciation in insects. Trends Ecol. Evol., 9, 388-392.

HEWITT, G. M. 1988. Hybrid zones-natural laboratories for evolutionary studies. Trends Ecol. Evol., 3, 158-167.

HEWITT, G. M. 1989. The subdivision of species by hybrid zones. In: Otte, D. and Endler, J. A. (eds) Speciation and its Consequences, pp. 85-110. Sinauer Associates, Sunderland, MA.

HEWITT, G. M. 1996. Some genetic consequences of ice ages, and their role in divergence and speciation. Biol. J. Linn. Soc., 58, 247-276.

LÖFSTEDT, C. 1993. Moth pheromone genetics and evolution. Phil. Trans. R. Soc. B, 340, 167-177.

MEYER, A., MORRISEY, J. M. AND SCHARTL, M. 1994. Recurrent origin of a sexually selected trait in Xiphophorus fishes inferred from a molecular phylogeny. Nature, 368, 539-542.

MILlAN, T., OSUNA, F., COBOS, S., TORRES, A. M. AND CUBERo, J. 1. 1996. Using RAPDs to study phylogenetic 
relationships in Rosa. Theor. Appl. Genet., 92, 273-277.

NEI, M. AND LI, w.-H. 1979. Mathematical model for studying genetic variation in terms of restriction endonucleases. Proc. Natl. Acad. Sci. U.S.A., 76, 5269-5273.

oudman, L., LANDMAn, w. AND DUiJM, M. 1989. Genetic distance in the genus Ephippiger (Orthoptera, Tettigonioidae) - a reconnaissance. Tijd. v. Entomol, 132, $177-181$.

OUdman, L., DUiJM, M. AND LANDman, w. 1990. Morphological and allozyme variation in the Ephippiger ephippiger complex (Orthoptera: Tettigonioidae). Neth. J. Zool., 40, 454-483.

RIESEBERG, L. H. 1996. Homology among RAPD fragments in interspecific comparisons. Mol. Ecol., 5, 99-105.

RITCH1E, M. G. 1991. Female preference for 'song races' of Ephippiger ephippiger (Orthoptera: Tettigoniidae). Anim. Behav, 42, 518-520.

RITCHIE, M. G. 1992. Behavioural coupling in tettigoniid hybrids (Orthoptera). Behav. Genet., 22, 369-379.

RITCHIE, M. G. 1996. The shape of female mating preferences. Proc. Natl. Acad. Sci. U.S.A., 93, 14628-14631.

RITCHIE, M. G. AND GLEASON, J. M. 1995. Rapid evolution of courtship song pattern in Drosophila willistoni sibling species. J. Evol. Biol., 8, 463-479.

RYAN, M. J. AND RAND, A. S. 1995. Female responses to ancestral advertisement calls in Túngara frogs. Science, 269, 390-392.

STAMMERS, M., HARRIS, G., EVANS, G. M., HAYWARD, M. D. AND FORSTER, J. W. 1995. Use of random PCR (RAPD) technology to analyse phylogenetic relationships in the
Lolium/Festuca complex. Heredity, 74, 19-27.

SIILES, J. F., LEMME, C., SONDUR, S., MORSHIDI, M. B. AND MANSHARDT, R. 1993. Using randomly amplified polymorphic DNA for evaluating genetic relationships among papaya cultivars. Theor. Appl. Genet., 85, $697-701$.

VAN DE ZANDE, L. AND BIJLSMA, R. 1995. Limitations of the RAPD technique in phylogeny reconstruction in Drosophila.J. Evol. Biol., 8, 645-656.

WELLS, M. M. AND HENRY, C. S. 1994. Behavioral responses of hybrid lacewings (Neuroptera: Chrysopidae) to courtship song. J. Insect Behav, 7, 649-662.

WELSH, J. AND MCCLELlAND, M. 1990. Fingerprinting genomes using PCR with arbitrary primers. Nucl. Acids Res., 18, 7213-7218.

WiLLiAMS, J. G. K., KUBELIK, A. R., LIVAK, K. J., RAFALSK1, J. A. AND TINGEY, S. V. 1990. DNA polymorphisms amplified by arbitrary primers are useful as genetic markers. Nucl. Acids Res., 18, 6531-6535.

wood, T. K. 1993. Speciation in the Enchenopa binotata complex (Homoptera: Membracidae). In: Lees, D. R. and Edwards, D. (eds) Evolutionary Patterns and Processes, pp. 299-317. Academic Press Linnean Society of London, London.

WU, C.-1, HOllocher, H., BEGUN, D. J., AQUADRO, C. F., XU, Y. AND wu, M.-L. 1995. Sexual isolation in Drosophila melanogaster: A possible case of incipient speciation. Proc. Natl. Acad. Sci. U.S.A., 92, 2519-2523.

WU, C.-I, JOHNSON, N. A. AND PALOPOLI, M. F. 1996. Haldane's rule and its legacy: why are there so many sterile males? Trends Ecol. Evol., 11, 281-284. 